\section{Pelottomasti arvokkaan ihmisyyden puolesta}

Suoranta, Juha (2019). Paulo Freire. Sorrettujen pedagogi. Into. 180 sivua.

HENKILÖKUVA Paulo Freirestä rakentuu hänen toimintansa kautta. Professori Juha Suoranta esittelee Freiren yhteiskuntarakenteiden radikaalina uudistajana.

Lähestymisnäkökulmaansa hän perustelee sillä, että Freiren ansiosta "käytössämme on ajatteluperinne, jossa kehitellään ja herätellään ajatuksia dialogisesta oppimisesta ja opettamisesta, kriittisestä tietoisuudesta sekä yhteiskunnallisen vallan ja vallankumouksen suhteista”.

Muotoseikat Suoranta esittelee tyylillä, mutta niiden syvällisemmän käsittelyn hän jättää muille. Muotoseikkoihin kuuluu Freiren (1921-1997) elämänkulun kuvaileminen, jossa kiteytyy se, että hän eli elämänsä ympärillään olevaa maailmaa rakastaen. Ehkä juuri sen vuoksi hänet tunnetaan kaikkialla maailmassa.

Freire syntyi Brasiliassa. Hän opiskeli oikeustieteitä, mutta valmistuttuaan juristiksi siirtyi sosiaali-, terveys- ja koulutusjärjestön palvelukseen. Hän väitteli teollistumisen ja kaupungistumisen haasteista brasilialaisessa yhteiskunnassa ja siirtyi täydennyskoulutuskeskuksen johtajaksi. Sieltä käsin Freire suunnitteli kansallisen lukutaitokampanjan Brasilian hallitukselle.

Sotilasvallankaappauksen aikoina vuonna 1964 Freire oli kaksi ja puoli kuukautta tutkintavankeudessa kansainvälisen kommunistisen aatteen edistämisestä epäiltynä. Syytöstä ei kuitenkaan pystytty näyttämään toteen. Vapauduttuaan hän päätti muuttaa Chileen.

Tie vei edelleen Yhdysvaltoihin Cambridgen yliopistoon vierailevaksi professoriksi ja sieltä Sveitsiin Kirkkojen maailmanneuvoston palvelukseen. Vuonna 1980 Freire palasi Brasiliaan, jossa hän toimi São Paulon kaupungin koulutoimenjohtajana.

\section{TAVOITTEENA KANSALAISTEN YHTEISKUNNALLINEN TOIMIJUUS}

Suorannan mukaan Freiren kumouksellisen puolen esiin tuleminen alkoi oivalluksesta tutkintavankeudessa. Hän havahtui siihen, että ihmisten yhteistoiminta oli oleellista paremman maailman rakentamisessa.

'Parempi maailma' viittaa Freirella ihmisen inhimillistymiseen. Tähän tarvittiin dialektista materialismia, mikä viittaa ihmisen ja häntä ympäröivien olojen väliseen suhteeseen. Oloja voidaan halutessa muuttaa, koska ne ovat huomattavalta osalta ihmisen luomia.

Jotta kansalaiset voimaantuisivat oman elämänsä ja tulevaisuuden tekijöiksi - sen sijaan että

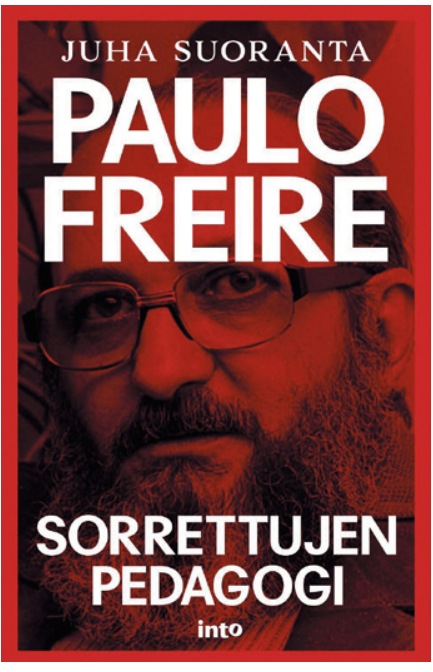

ajelehtivat kohtalonomaisesti - heidän pitää tulla tietoisiksi yhteiskunnallisista käytännöistä ja niiden rakentumisen periaatteista. Yhteiskunnallinen toimeliaisuus lisää kriittistä tiedostamista, auttaa tunnistamaan oman ja muiden elämän sekä olojen rakentumisen ja historian välisiä yhteyksiä. Tällä tavoin vapaudutaan toimimaan paremman maailman puolesta.

Freire tavoitteli kansalaisten yhteiskunnallista toimijuutta. Siihen kasvamisessa hän uskoi dialogisuuden uutta luovaan voimaan. Parhaimmillaan dialoginen kohtaaminen on Freiren mukaan silloin, kun sitä luonnehtii pyrkimys oppia yhdessä. Siihen taas tarvitaan maailman rakastamista, periksiantamatonta uskoa ihmisen mahdollisuuksiin, huomiseen kannattelevaa toivoa ja nöyryyttä, joka auttaa oppimaan uutta.

Yhteiskunta muodostuu kansalaisista. Uuden oppiminen on Freirelle yhteiskunnallisen uudistumisen lähtökohta. Ilman itsen jatkuvaa ylittämistä ihmisen liike 


\section{FREIRE ELI ELÄMÄNS̈̈ YMPÄRILLÄ̈̈N}

\section{OLEVAA MAAILMAA RAKASTAEN.}

pysähtyy ja yhteiskunta taantuu. Menneisyydestä voi oppia, kuka on ja mistä tähän hetkeen on tullut, mutta päivä päivältä viisaampi tulevaisuuden tekeminen on menneisyyteen katsomista oleellisempaa, Freire uskoo.

\section{KUVITTELUKYKY ON NÄKÖALATTOMUUDEN VASTAVOIMA}

Koska tulevaisuutta ei vielä ole, sen viisaassa rakentamisessa tarvitaan kuvittelukykyä, joka on näköalattomuuden vastavoima. Kuvittelukyvyn avulla on mahdollista tunnistaa vaihtoehtoisia elämisen ja olemisen tapoja.
Jokaisessa ihmisessä olevat koettelemattomat mahdollisuudet ja vielä olemassa olematon maailma ovat Freiren elämänfilosofian kulmakivi.

Ihmiskunta elää ennennäkemättömän muutostarpeen keskellä. Elämän edellytysten säilymisen ja jokaisen ihmisen arvokkuuden puolesta toimiminen on aikakautemme imperatiivi. Ymmärrämme, että olemassa olevien latuurien parantelu ei auta, vaan tarvitaan kokonaan uuteen suuntaan vievät ladut. Freiren ajatteluun tutustuminen auttaa ottamaan tulevaisuutta haltuun niin, että vielä olematonta hyvää aletaan tekemään olemassa olevaksi hyväksi.
Tässä tarvitaan kumouksellista otetta, joka on kyllästetty tahdolla, näkemyksellisyydellä ja määrätietoisuudella.

Juha Suorannan piirtämä kuva Paulo Freirestä on ajankohtaisuudessaan perin suositeltavaa luettavaa. Teos on helppolukuinen mutta syvällinen. Se sopii monenlaiseen käyttöön.

\section{ARTO O. SALONEN}

$K T$, apulaisprofessori Itä-Suomen yliopisto kasvatustieteen dosentti Helsingin yliopisto sosiaalipedagogiikan dosentti Itä-Suomen yliopisto kestävän kehityksen dosentti Maanpuolustuskorkeakoulu

\section{Klassikot palaavat}

Vuonna 2020 alkava "Klassikon paluu" -esseesarja esittelee teoksia, jotka ovat olleet lukijalleen merkityksellisiä tutkimuksessa, opinnoissa ja työssä.

"Klassikon paluu" rakentaa vuorovaikutusta tutkijayhteisössä yli sukupolvien ja avaa tutkimusta tiedeyhteisöä laajemmalle yleisölle.
Tekstejä on mahdollista hyödyntää myös oppimateriaalina.

Kukin essee muodostaa yhden säkeen aikuiskasvatustieteen klassikoiden kaanonissa.

Tutustu kirjoittajaohjeisiin ja tarjoa tekstiä: aikuiskasvatus.fi/ohjeitakirjoittajalle/lehden-osastot 